ORIGINAL ARTICLE, MEDICINE

\title{
Changes in Hematologic and Coagulation Profiles in Rabbits with Right-ventricle Pacing
}

\section{Ivana Uhrikova ${ }^{1}$, Milan Sepsi ${ }^{2}$, Jana Hlozkova ${ }^{3}$, Pavel Suchy ${ }^{3}$, Marta Kasajova ${ }^{4}$, Katerina Machackova ${ }^{1}$, Delian P. Delev5 ${ }^{5}$, Rachele Ciccocioppo ${ }^{6}$, Peter Kruzliak ${ }^{7,8}$, Peter Scheer ${ }^{3,9}$}

${ }^{1}$ Department of Physiology, Faculty of Veterinary Medicine, University of Veterinary and Pharmaceutical Sciences, Brno, Czech Republic

${ }^{2}$ Department of Internal Medicine and Cardiology, University Hospital, Brno, Czech Republic

${ }^{3}$ Department of Human Pharmacology and Toxicology, Faculty of Pharmacy, University of Veterinary and Pharmaceutical Sciences, Brno, Czech Republic

${ }^{4}$ Department of Industrial Engineering, Faculty of Mechanical Engineering, University of Zilina, Zilina, Slovakia

${ }^{5}$ Department of Pharmacology and Clinical Pharmacology, Medical Faculty, Medical University of Plovdiv, Plovdiv, Bulgaria

${ }^{6}$ Department of Internal Medicine, Fondazione IRCCS Policlinico San Matteo, Università degli Studi di Pavia, Pavia, Italy

${ }^{7}$ Laboratory of Structural Biology and Proteomics, Faculty of Pharmacy, University of Veterinary and Pharmaceutical Sciences, Brno, Czech Republic

${ }^{8} 2^{\text {nd }}$ Department of Surgery, Faculty of Medicine, Masaryk University, Brno, Czech Republic

${ }^{9}$ Veterinary Clinic MaScHEER, Malesovice, Czech Republic

Correspondence: Peter Kruzliak, Laboratory of Structural Biology and Proteomics, Faculty of Pharmacy, University of Veterinary and Pharmaceutical Sciences, Palackeho tr 1946/1, Brno, 61242

Czech Republic

E-mail: peter.kruzliak@savba.sk

Tel: +420543181111

Fax: +420543181111

Received: 10 May 2016

Accepted: 17 May 2016

Published: 30 June 2016

Key words: D-dimer, pacemaker, right-ventricle pacing, thromboelastography, coagulation profile

Citation: Uhrikova I, Sepsi M, Hlozkova J, Suchy P, Kasajova M, Machackova K, Delev DP, Ciccocioppo R, Kruzliak P, Scheer P Changes in Hematologic and coagulation profiles in rabbits with right-ventricle pacing.

Folia Medica 2016;58(2);89-94,

doi: 10.1515/folmed-2016-0013
Objectives: The aim of this study was to evaluate changes in hematology and coagulation in rabbits with right-ventricle pacing without medication.

Animals and methods: Blood was collected from ten non-anesthetized male rabbits from the jugular vein before and one month after pacemaker placement. Total erythrocyte, leukocyte and platelet count, hemoglobin, hematocrit and differential leukocyte count were done on automatic veterinary flow cytometry hematologic analyzer. Prothrombin time, activated partial thromboplastin time, fibrinogen level, D-dimers and kaolin-activated thromboelastography was measured from citrated blood.

Results: We found an increase in red blood cell mass and decrease in platelet count, while coagulation tests did not differ between samplings.

Conclusion: Right-ventricle pacing seems to have no influence on hemostasis in rabbits.

\begin{abstract}
Abbreviations used in the article
aPTT - activated partial thromboplastin time, FDP - fibrin degradation products, MA - maximal amplitude, MCH - mean corpuscular hemoglobin, MCHC - mean corpuscular hemoglobin concentration, MCV - mean corpuscular volume, $\mathrm{K}$ speed of clot formation , LY30 - percent of clot lysed after $30 \mathrm{~min}, \mathrm{R}$ - reaction time
\end{abstract}

\section{INTRODUCTION}

Placement of a permanent pacemaker in humans is associated with a number of clinical and laboratory findings such as pre-thrombotic state ${ }^{1}$, clot formation on electric leads ${ }^{2}$ or thrombosis ${ }^{3,4}$, whilst other studies did not confirm the presence of thrombosis in patients with pacemaker ${ }^{5}$. Pacemaker placement is common also in veterinary medicine, mainly in dogs and cats ${ }^{6,7}$, and thrombotic complications in the latter have been described as well ${ }^{8}$. However, it is not clear if the common cause of these complications is a primary cardiac disease, the foreign material in the heart and vessels or a combination of both.

Rabbits are frequently used as laboratory animals, mainly due to easy manipulation and adequate size. Moreover, by considering that the coagulation system of each animal is different, it is worth noting that rabbits are routinely used as model animals for evaluation of hemostasis. The most common studies are about thrombotic disorders, because rabbits' 
platelet function is similar to that in humans.9-11 Up to date, the hematologic or coagulation changes in rabbits with right-ventricle pacing have not yet been studied. The aim of this study, therefore, was to compare the changes in hematology and coagulation in healthy rabbits before and after permanent transvenous right-ventricle pacing for evaluation of pure pacemaker presence on hemostasis.

\section{MATERIAL AND METHODS}

\section{Animals}

Ten clinically healthy New Zealand white rabbits (albino) were used in this study. They were all males with an average weight of $3.1 \mathrm{~kg}$ (range $2.9-3.3 \mathrm{~kg}$ ) and age of 14 weeks. The rabbits were vaccinated against myxomatosis and plague (Pestorin Mormyx Bioveta a.s., Ivanovice na Hane, Czech Republic) two weeks prior to first blood collection. The animals were kept in metal cages $(50 \times 60 \times 70 \mathrm{~cm})$ during the experiment. The cages were situated in a room with a temperature of $19 \pm 1{ }^{\circ} \mathrm{C}$ and relative air humidity between 55 and $60 \%$. The complete feed mixture (Biostan KV, Biosta Blučina, Czech Republic) and drinking water were administered $a d$ libitum. A natural light regimen was maintained, health condition was checked daily.

After a period of adaptation (4 weeks), the rabbits underwent anesthesia and a right-ventricle pacemaker was placed in all animals. Due to the anatomical situation in this breed, implantations of pacemaker were done through the vena jugularis externa sinistra. Induction to anesthesia was performed using diazepam $(2 \mathrm{mg} / \mathrm{kg}$ b.w., i.m., Apaurin inj., KRKA d.d. Novo mesto, Slovenia), ketamine (35 mg/kg b.w., i.m., Narketan $100 \mathrm{mg} / \mathrm{mL}$ inj., Vétoquinol s.r.o. Nymburk, Czech Republic) and xylazine $(5 \mathrm{mg} / \mathrm{kg}$ b.w., i.m., Xylapan $20 \mathrm{mg} / \mathrm{mL}$ inj., Vétoquinol s.r.o. Nymburk, Czech Republic). Basal anesthesia was maintained using $0.5-1.5 \%$ mixture of oxygen and isoflurane (Aerrane, Baxter Manufacturing Sp. z o.o., Lublin, Poland). Infusion therapy was maintained through the auricular vein. After a close shave of ventricular part of the neck, place for pacemaker in front of musculus suprascapularis and thorax, ultrasonography for exclusion of inherited heart disease was performed. The animal was positioned on its right side; vena jugularis externa sinistra was prepared. Ligation of cranial branches of $v$. jugularis externa sinistra was performed, on caudal pole two strands were used for fixation of electrode in the vessel. The electrode with active fixation (Tendril ST 1888TC/52 $\mathrm{cm}$, St. Jude Medical, Minnesota, US) was placed in right ventricle and then fixated in the vessel. A pocket for pacemaker was prepared in suprascapular region and pacemaker (Sustain XL SC 1134, Verity XL SC 5056, Sustain XL SR 1136 or Sustain XL DC 2134, St. Jude Medical, Minnesota, US) was connected to the electrode. After suture, pacemaker with blinded atrial port was checked and set to stimulation 170/min (physiologic for rabbits), ejection $3.5 \mathrm{~V} / 0.4 \mathrm{msec}$, sensitivity based on $\mathrm{R}$ wave $0.1 \mathrm{mV}$. After surgery, rabbits received marbofloxacin $(2 \mathrm{mg} / \mathrm{kg}$, s.c. $/ 48$ hours $)$ and tolfenamic acid ( $4 \mathrm{mg} / \mathrm{kg}$ b.w., s.c. $/ 48$ hours) for 7 days. The experiment was made in compliance with Act. No. 246/1992 on the Protection of Animals from Maltreatment, as later amended. The experimental protocol was approved by the expert committee for ensuring the welfare of experimental animals and Ministry of Education, Youth and Sport under the number 53/2013.

\section{BLOOD COLLECTION}

Blood samples were harvested one day before and one month after pacemaker placement from the vena jugularis externa and collected into citrate and EDTA (Dispolab s.r.o., Brno, Czech Republic) test tubes. Hematologic examination (measurement of total erythrocyte, leukocyte and platelet count, hemoglobin, hematocrit, mean corpuscular volume, mean corpuscular hemoglobin, mean corpuscular hemoglobin concentration and differential leukocyte count) was performed from EDTA blood samples on automated hematologic analyzer (Sysmex XT 2000iV, Sysmex Corporation, Kobe, Japan) within 10 minutes. One milliliter of citrated blood was separated for kaolin-activated thromboelastography (TEG, TEG ${ }^{\circledR}$ 5000 Thromboelastograph ${ }^{\circledR}$ Hemostasis System, Hemoscope Corporation, Illinois, USA) and the rest of the blood sample was centrifuged $(1000 \mathrm{~g}, 10 \mathrm{~min})$ and used for coagulation analysis. Measurement of prothrombin time (PT; thromboplastin-S, Dialab, s.r.o., Prague, Czech Republic), activated partial thromboplastin time (aPTT; APTT-S, Dialab, s.r.o., Prague, Czech Republic; $0.025 \mathrm{M} \mathrm{CaCl}_{2}$, Dr. Kulich Pharma, s.r.o., Hradec Kralove, Czech Republic), thrombin time and fibrinogen (TT, FBG, Bovinní trombin 100 NIH U/mL, Dialab, s.r.o., Prague, Czech Republic) was performed on two-channel analyzer (Coatron M2, Teco, Hilden, Germany). Coagulation analysis including D-dimers (NycoCard D-dimers, Axis-Shield PoC, Oslo, Norway) was performed within 1 hour from blood collection. 


\section{STATISTICAL ANALYSIS}

Data were statistically analysed (MedCalc bvba, Ostend, Belgium). Both the hematologic and coagulation parameters (before and after pacemaker placement) were compared using the Wilcoxon paired test with a significance level set at $\mathrm{p}<0.05$.

\section{RESULTS}

Significant differences were found in erythrocyte count, hematocrit, hemoglobin and platelet count before and after pacemaker placement (Table 1). After pacemaker insertion, a significant increase in erythrocytes, hemoglobin and hematocrit and drop in platelet count was observed.

Results from coagulation tests are listed in Table 2. There were no significant differences in the routine coagulation parameters and kaolin-induced thromboelastography before and after pacemaker insertion.

\section{DISCUSSION}

Pacemaker placement in human medicine is often connected with anticoagulant or antiplatelet medi- cation. This is why a prethrombotic state has been demonstrated in patients with long-term transvenous pacing even without evident thrombosis. ${ }^{1}$ Moreover, another work focused on clot formation on cardiac device leads demonstrated that thrombi development is significantly associated with atrial fibrillation. Among patients with clot formation, $20 \%$ did not receive anticoagulant/antiplatelet therapy, $40 \%$ received antiplatelet therapy, 13\% received anticoagulant therapy, $27 \%$ received both antiplatelet and anticoagulant therapy. ${ }^{2}$ Since 2009, we have performed 25 successful pacemaker placements in dogs and one cat with no need of further anticoagulant or antiplatelet medication. Thus, we were wondering if there were any changes in hematologic and coagulation profile caused by pure pacemaker implantation. We have chosen rabbits as model animal due to easy manipulation, standardized procedure and relatively large size of lead in comparison to the body.

The hematologic exams before pacing were similar to those previously published for rabbits. ${ }^{12,13}$ Furthermore, we found a lower range of the mean corpuscular volume (MCV) in comparison to that

Table 1. Hematologic examination before and after pacemaker placement

\begin{tabular}{|c|c|c|c|c|c|c|}
\hline Parameter & Unit & Sampling & Median & Min & Max & $\mathbf{p}$ \\
\hline \multirow{2}{*}{ Leukocyte count } & \multirow{2}{*}{$* 10^{9} / \mathrm{L}$} & before & 7.8 & 6.4 & 11.0 & \multirow{2}{*}{0.06} \\
\hline & & after & 6.5 & 3.1 & 9.8 & \\
\hline \multirow{2}{*}{ Erythrocyte count } & \multirow{2}{*}{$* 10^{12} / \mathrm{L}$} & before & 6.1 & 5.4 & 7.4 & \multirow{2}{*}{$0.04 *$} \\
\hline & & after & 6.8 & 6.3 & 7.8 & \\
\hline \multirow[t]{2}{*}{ Hemoglobin } & \multirow[t]{2}{*}{$\mathrm{g} / \mathrm{L}$} & before & 127 & 111 & 143 & \multirow[t]{2}{*}{$<0.05^{*}$} \\
\hline & & after & 138 & 124 & 159 & \\
\hline Hematocrit & $\%$ & $\begin{array}{l}\text { before } \\
\text { after }\end{array}$ & $\begin{array}{l}39 \\
42\end{array}$ & $\begin{array}{l}35 \\
39\end{array}$ & $\begin{array}{l}45 \\
47\end{array}$ & $0.02 *$ \\
\hline \multirow{2}{*}{$\mathrm{MCV}$} & \multirow{2}{*}{$\mathrm{fL}$} & before & 64.2 & 56.9 & 75.0 & \multirow{2}{*}{0.51} \\
\hline & & after & 60.8 & 54.8 & 66.9 & \\
\hline \multirow{2}{*}{$\mathrm{MCH}$} & \multirow{2}{*}{ pg } & before & 20.7 & 19.1 & 21.4 & \multirow{2}{*}{0.51} \\
\hline & & after & 20.4 & 17.9 & 22.0 & \\
\hline \multirow{2}{*}{$\mathrm{MCHC}$} & \multirow{2}{*}{$\mathrm{g} / \mathrm{L}$} & before & 323 & 286 & 340 & \multirow{2}{*}{0.37} \\
\hline & & after & 327 & 292 & 351 & \\
\hline \multirow[t]{2}{*}{ Platelet count } & \multirow[t]{2}{*}{$* 10^{9} / \mathrm{L}$} & before & 430 & 361 & 604 & \multirow{2}{*}{$<0.01 *$} \\
\hline & & after & 294 & 69 & 414 & \\
\hline Neutrophils & $* 10^{9} / \mathrm{L}$ & before & 1.9 & 1.4 & 2.6 & 0.14 \\
\hline \multirow{2}{*}{ Monocytes } & \multirow{2}{*}{$* 10^{9} / \mathrm{L}$} & $\begin{array}{l}\text { atter } \\
\text { before }\end{array}$ & $\begin{array}{l}1.3 \\
0.6\end{array}$ & $\begin{array}{l}0.3 \\
0.4\end{array}$ & $\begin{array}{l}3.8 \\
0.8\end{array}$ & \multirow[b]{2}{*}{0.13} \\
\hline & & after & 0.4 & 0.0 & 0.9 & \\
\hline \multirow{2}{*}{ Lymphocytes } & \multirow{2}{*}{$* 10^{9} / \mathrm{L}$} & before & 4.8 & 3.7 & 7.1 & \multirow{2}{*}{0.19} \\
\hline & & after & 4.0 & 2.9 & 6.3 & \\
\hline Eosinophils & $* 10^{9} / \mathrm{L}$ & before & 0.07 & 0.02 & 0.5 & 0.81 \\
\hline Basophils & & before & $\begin{array}{l}0.07 \\
0.4\end{array}$ & $\begin{array}{l}0.0 \\
0.0\end{array}$ & $\begin{array}{l}0.1 \\
1.4\end{array}$ & \\
\hline Basophils & $* 10^{9} / \mathrm{L}$ & after & 0.3 & 0.0 & 0.7 & 0.13 \\
\hline
\end{tabular}

* - significant difference between samplings 
Table 2. Coagulation tests before and after pacemaker placement

\begin{tabular}{|c|c|c|c|c|c|c|}
\hline Parameter & Unit & Sampling & Median & Min & $\operatorname{Max}$ & $\mathbf{p}$ \\
\hline aPTT & $\mathrm{S}$ & $\begin{array}{l}\text { before } \\
\text { after }\end{array}$ & $\begin{array}{l}21.0 \\
20.8\end{array}$ & $\begin{array}{l}16.9 \\
16.0\end{array}$ & $\begin{array}{l}40.2 \\
31.0\end{array}$ & 0.96 \\
\hline Prothrombin time & $\mathrm{s}$ & $\begin{array}{l}\text { before } \\
\text { after }\end{array}$ & $\begin{array}{l}10.4 \\
10.1\end{array}$ & $\begin{array}{l}9.2 \\
9.5\end{array}$ & $\begin{array}{l}12.6 \\
13.7\end{array}$ & 0.92 \\
\hline Thrombin time & $\mathrm{s}$ & $\begin{array}{l}\text { before } \\
\text { after }\end{array}$ & $\begin{array}{l}15.6 \\
17.9\end{array}$ & $\begin{array}{l}13.4 \\
16.0\end{array}$ & $\begin{array}{l}33.1 \\
23.3\end{array}$ & 0.14 \\
\hline Fibrinogen & $\mathrm{g} / \mathrm{L}$ & $\begin{array}{l}\text { before } \\
\text { after }\end{array}$ & $\begin{array}{l}1.8 \\
2.0\end{array}$ & $\begin{array}{l}1.4 \\
1.7\end{array}$ & $\begin{array}{l}4.8 \\
3.4\end{array}$ & 0.76 \\
\hline D-dimers & $\mathrm{mg} / \mathrm{L}$ & $\begin{array}{l}\text { before } \\
\text { after }\end{array}$ & $\begin{array}{l}0.1 \\
0.1\end{array}$ & $\begin{array}{l}<0.1 \\
<0.1\end{array}$ & $\begin{array}{l}1.7 \\
0.4\end{array}$ & 0.21 \\
\hline $\mathrm{R}$ & $\min$ & $\begin{array}{l}\text { before } \\
\text { after }\end{array}$ & $\begin{array}{l}5.1 \\
4.6\end{array}$ & $\begin{array}{l}3.6 \\
3.9\end{array}$ & $\begin{array}{l}9.2 \\
5.2\end{array}$ & 0.68 \\
\hline K & $\min$ & $\begin{array}{l}\text { before } \\
\text { after }\end{array}$ & $\begin{array}{l}1.7 \\
1.2\end{array}$ & $\begin{array}{l}0.8 \\
1.1\end{array}$ & $\begin{array}{l}3.1 \\
2.5\end{array}$ & 0.80 \\
\hline$\alpha$ angle & $\circ$ & $\begin{array}{l}\text { before } \\
\text { after }\end{array}$ & $\begin{array}{l}64.3 \\
70.9\end{array}$ & $\begin{array}{l}52.4 \\
56.9\end{array}$ & $\begin{array}{l}77.0 \\
75.2\end{array}$ & 0.75 \\
\hline MA & $\mathrm{mm}$ & $\begin{array}{l}\text { before } \\
\text { after }\end{array}$ & $\begin{array}{l}63.7 \\
63.6\end{array}$ & $\begin{array}{l}56.4 \\
52.8\end{array}$ & $\begin{array}{l}69.3 \\
56.4\end{array}$ & 0.75 \\
\hline LY30 & $\%$ & $\begin{array}{l}\text { before } \\
\text { after }\end{array}$ & $\begin{array}{l}0 \\
0\end{array}$ & $\begin{array}{l}0 \\
0\end{array}$ & $\begin{array}{l}0 \\
0\end{array}$ & NA \\
\hline
\end{tabular}

reported by Marshall et al. ${ }^{12}$, and higher erythrocyte and leukocyte counts, with a high number of neutrophils, monocytes and lymphocytes, but lower eosinophils with respect to data from Jeklova et $a 1^{13}$. Basophil count was very similar. The reason for this discrepancy may lie in holding conditions, since our rabbits were kept in the conventional system and those of Jeklova et al. ${ }^{13}$ in specificpathogen-free system. After pacemaker placement, a significant increase in red blood cell count, hemoglobin and hematocrit was observed. The most probable reason of this increase was an elevation in red blood cell mass due to the growth of the animals as was described previously ${ }^{12}$ since the second blood sampling was harvested one month after the first sampling (median weight $3.1 \mathrm{~kg}$ vs. $3.5 \mathrm{~kg}$ ). The decrease in platelet count could indicate an increased consumption; however, a further test does not confirm the hypercoagulability state, and both median platelet counts were within reference range published for New Zealand rabbits. ${ }^{14}$

As far as the coagulation tests are concerned, prothrombin time and aPTT were similar to those previously published, whilst thrombin time was shorter and fibrinogen level lower than those reported by Mochizuki et al. ${ }^{15}$ Results from thromboelastography differed from previously published results. ${ }^{16}$ Indeed, reaction time (R-time) and speed of clot formation (K-time) were longer in our study and $\alpha$ angle was lower indicating generally slower clot formation. Difference between studies may be due to the different protocols used: Shimokawa et al. ${ }^{16}$ collected blood from anesthetized animals whilst we did not use any medication prior to blood collection, and it is not clear what type of activator they used for measurement. In addition, we performed our study only on male rabbits, whereas in the mentioned study only female animals were used. ${ }^{16}$ To our best knowledge, this is the first study reporting kaolin-activated thromboelastography in rabbits. The significant influence of gender on thromboelastography results has been repeatedly proven in humans with the same pattern, where males had higher values of R-time, K-time and lower values for $\alpha$ angle and MA. ${ }^{17,18}$ After rightventricle pacing, there were no significant changes in coagulation tests indicating that placement of a pacemaker in rabbits was probably not associated with hypocoagulability or hypercoagulability at the time of measurement. Fibrinogen concentration and thrombin time were slightly increased, but interference with fibrinogen degradation products (FDP) seems to be ruled out because levels of D-dimers were low. Also, FDP does not increase fibrinogen levels in rabbits. ${ }^{19}$ In conclusion, the results of this study indicate that pure insertion of pacemaker is not associated with hematologic and coagulation changes and then anticoagulant and antiplatelet medication is not needed. 


\section{ACKNOWLEDGEMENT}

The study was supported by grant IGA MH CZ NT14591-3.

\section{REFERENCES}

1. Ito T, Tanouchi J, Kato J, et al. Prethrombotic state due to hypercoagulability in patients with permanent transvenous pacemakers. Angiology 1997;48:901-6.

2. Rahbar AS, Azadani PN, Thatipelli S, et al. Risk factors and prognosis for clot formation on cardiac device leads. Pacing Clin Electrophysiol 2013;36:1294-300.

3. Kennedy PA, Shipley RE, Prozan GB, et al. Three years' experience with long-term endocardiac pacing. Complications: their care and prevention. Am J Surg 1968;116:164-169.

4. Williams EH, Tyers GF, Shaffer CW. Symptomatic deep venous thrombosis of the arm associated with permanent transvenous pacing electrodes. Chest 1978;73:613-5.

5. Gillette PC, Zeigler V, Bradham GB, et al. Pediatric transvenous pacing: a concern for venous thrombosis? Pacing Clin Electrophysiol 1988;11:1935-9.

6. Fox PR, Moise NS, Woodfield JA, et al. Techniques and complications of pacemaker implantation in four cats. J Am Vet Medical Assoc 1991;199:1742-53.

7. Wess G, Thomas WP, Berger DM, et al. Applications, complications, and outcomes of transvenous pacemaker implantation in 105 dogs (1997-2002). J Intern Vet Med 2006;20:877-884.

8. Cunningham SM, Ames MK, Rush JE, et al. Successful treatment of pacemaker-induced stricture and thrombosis of the cranial vena cava in two dogs by use of anticoagulants and balloon venoplasty. J Am Vet Medical Assoc 2009;235:1467-73.

9. Siller-Matula JM, Plasenzotti R, Spiel A, et al. Inter- species differences in coagulation profile. Thromb Hemost 2008;100:397-404.

10. Larsson M, Rayzman V, Nolte MW, et al. A factor XIIa inhibitory antibody provides thromboprotection in extracorporeal circulation without increasing bleeding risk. Sci Transl Med 2014;6:222ra17.

11. Xu Y, Cai TQ, Castriota G, et al. Factor XIIa inhibition by Infestin-4: in vitro mode of action and in vivo antithrombotic benefit. Thromb Haemost 2014;111:694-704.

12. Marshall KL. Rabbit hematology. Vet Clin North Am Exotic Anim Pract 2008;11:551-567.

13. Jeklova E, Leva L, Knotigova P, et al. Age-related changes in selected hematology parameters in rabbits. Res Vet Sci 2009;86:525-528.

14. Hewitt CD, Innes DJ, Savory J, et al. Normal biochemical and hematological values in New Zealand white rabbits. Clin Chem 1989;35:1777-1779.

15. Mochizuki M, Abe H, Wakabayashi K, et al. Changes in blood coagulation-related parameters in phenobarbital-treated rabbits. J Toxicol Sci 2009;34:357-362.

16. Shimokawa M, Kitaguchi K, Kawaguchi M, et al. The influence of induced hypothermia for hemostatic function on temperature-adjusted measurements in rabbits. Anesth Analg 2003;96:1209-1213.

17. Scarpelini S, Rhind SG, Nascimento B, et al. Normal range values for thromboelastography in healthy adult volunteers. Brazil J Med Biol Res 2009;42:1210-1217.

18. Roeloffzen WW, Kluin-Nelemans HC, Mulder AB, et al. In normal controls, both age and gender affect coagulability as measured by thrombelastography. Anesth Analg 2010;110:987-994.

19. Otis PT, Rapaport SI. Failure of Fibrinogen Degradation Products to Increase Plasma Fibrinogen in Rabbits. Exp Biol Med (Maywood) 1973;144:124-129. 


\title{
Изменения гематологического и коагуляционного профиля кроликов посредством электростимуляции правой камеры
}

\author{
Ивана Урикова ${ }^{1}$, Милан Сепси ${ }^{2}$, Жана Хлозкова ${ }^{3}$, Павел Сухи ${ }^{3}$, Ралта Касайова ${ }^{4}$, \\ Катерина Махакова ${ }^{1}$, Делян П. Делев ${ }^{5}$, Рейчел Кикокиопо ${ }^{6}$, Петер Крузлиак ${ }^{7,8}$, Петер \\ Шeep ${ }^{3,9}$ \\ ${ }^{1}$ Кафедра физиологии, Факультет ветеринарной медицины, Университет ветеринарных и фармацевтических наук, Брно, \\ Чешская Республика \\ 2 Кафедра внутренней медицины и кардиологии, Университетская больница, Брно, Чешская Республика \\ 3 Кафедра гуманной фармакологии и токсикологии, Фармацевтический факультет, Университет ветеринарных и фарма- \\ цевтических наук, Брно, Чешская Республика \\ ${ }^{4}$ Кафедра промышленного инжиниринга, Факультет механотехники, Жилинский университет, Жилина, Словакия \\ ${ }^{5}$ Кафедра фармакологии и клинической фармакологии, Факультет медицины, Медицинский университет, Пловдив, \\ Болгария \\ ${ }^{6}$ Кафедра внутренней медицины, Fondazione IRCCS Policlinico San Matteo, Universitàdegli Studi di Pavia, Раvia, Италия \\ 7 Лаборатория по структурной биологии и протеомике, Фармацевтический факультет, Университет ветеринарных и \\ фармацевтических наук, Брно, Чешская Республика \\ 8 Вторая кафедра хирургии, Медицинский факультет, Масариков университет, Брно, Чешская Республика \\ ${ }^{9}$ Ветеринарная клиника MaScHEER, Malesovice, Чешская Республика
}

\section{Для корреспонденции: \\ Петер Крузлиак, \\ Лаборатория по структурной \\ биологии и протеомике, Фармацевтический факультет, Университет ветеринарных и фармацевтических наук, Palackehotr 1946/1, Брно, 612 42, Чешская Республика. \\ E-mail: peter.kruzliak@savba.sk Тел.: +420543181111 \\ Факс: +420543181111}

Дата получения: 10 мая 2016 г. Дата приемки: 17 мая 2016 г. Дата публикации: 30 мая 2016 г.

\section{Ключевые слова:}

D-димер, пейсмейкер, электростимуляция правой камеры, тромбоэластография, коагуляционный профиль

Цитаты: Урикова И, Сепси М, Хлозкова Ж, Сухи П, Касайова М, Махакова К, Делев ДП, Кикокиопо Р, Крузлиак П, Шеер П. Изменения гематологического и коагуляционного профиля кроликов посредством электростимуляции правой камеры. Folia Medica 2016;58(2);89-94, doi: 10.1515/folmed-2016-0013
Цели: Целью настоящего исследования является оценка изменений гематологии и коагуляции у кроликов посредством электростимуляции правой камеры без медикаментов.

Животные и методы: Взята кровь у десяти самцов кроликов без наркоза из яремной вены за месяц до и затем спустя месяц после установки пейсмейкера. Проведены полные анализы крови с исследованием показателей эритроцитов, лейкоцитов и тромбоцитов, гемоглобина, гематокрита и дифференциального подсчёта лейкоцитов, с использованием автоматического ветеринарного проточно-цитометрического гематологического анализатора. Цитратная кровь была использована для измерения показателей протромбинового времени, активированного частичного тромбопластинового времени, уровня фибриногена, D-димеров и каолин-активированной тромбоэластографии.

Результаты: Установлено увеличение массы красных кровяных телец и уменьшение количества тромбоцитов, в то же самое время по результатам коагуляционных тестов не установлено различие между пробами.

Заключение: Электростимуляция правой камеры очевидно не оказывает влияние на гемостаз у кроликов.

\section{Использованные в статье сокращения:}

аРТТ - активированное частичное тромбопластиновое время, FDP - продукты расщепления фибрина, МА - максимальная амплитуда, МСH - средний гемоглобин эритроцитов, МСНC - средняя концентрация гемоглобина в клетках, MCV - средний объем эритроцитов, K - скорость свертывания крови, LY30 - процент свертывания (показатель 30-минутного лизиса), R - время реакции. 